Acta Universitatis Wratislaviensis • No 4055

Literatura i Kultura Popularna XXVII, Wrocław 2021

https://doi.org/10.19195/0867-7441.27.15

Miodrag Milovanović

ORCID: 0000-0002-3090-3900

Comic Strip Art Centre/USAS, Belgrade, Serbia

\title{
Science Fiction in Belgrade in the 1920s: A Possible Contribution to the Development of Metropolitan Belgrade
}

Słowa kluczowe: science fiction, kultura popularna, kultura amerykańska, kultura serbska, metropolita Belgradu, Hugo Gernsback, Nikola B. Jovanović, Jelena Zrnić, Ivan Zrnić

Keywords: science fiction, popular culture, US culture, Serbian culture, metropolitan Belgrade, Hugo Gernsback, Nikola B. Jovanović, Jelena Zrnić, Ivan Zrnić

\section{Introduction}

Electrimir Powerson [Serb. orig. Strujomir Elektrićc, a guy from Belgrade famous for visiting all the renowned cinemas in the world, was returning in his nimble soloplane, built by Whoosh of London, peacefully cutting through the air at 50 miles per minute. Crafts of various sizes and brands whirled beside, around and below him, the letters of light-o-mercials constantly flashing along his path. All of a sudden, the machine shuddered and came to a halt. Electro only then noticed he had already arrived on Terazije Square. Just ahead of him, a Mark V traffic gendarme rocked in the air. With a radio-baton, the gendarme brought Powerson's apparatus to a dead halt in an instant. ${ }^{1}$

Serbian historiography and sociology lack material that describes the role of popular culture in the development of Belgrade as a modern metropolis after World War I. Some aspects of this problem are present in the works of historians

${ }^{1}$ B. Dimitrijević, "Posle sto godina" [A Hundred Years After], Reč i slika [Words and Images], 1926, p. 157. 
Predrag Marković ${ }^{2}$ and Ranka Gašić, ${ }^{3}$ art historian Simona Čupić, ${ }^{4}$ and other authors from various fields of culture and art: urbanism, architecture, fashion, etc. The most complete and most focused research of the influence that various pop culture incarnations - primarily the cabaret, movies, jazz, and other forms of entertainment — had on the development of Belgrade was undertaken by historian Jovana Babović. She supports the thesis that a group of entrepreneurs of medium financial power - publishers, cabaret and cinema owners, and the like - made a conscious effort to promote foreign forms of entertainment in an attempt to elevate Belgrade to the level of a European metropolis, a notion that the middle class gladly accepted. However, that weakened some aspects of the domestic entertainment industry and led to cultural segregation in the capital. ${ }^{5}$

The present essay aims to highlight the role of this small group of Belgrade's intellectuals and entrepreneurs in the popularization of an emerging genre - science fiction - as part of popular culture, focusing on the prose and illustrations related to the genre. The way in which US popular culture spread and began to compete with the previously dominant European influence by the mid-1920s will be examined. The author will make an attempt to determine if these processes contributed to the overall cultural background of Belgrade as a metropolis. It is believed that such influence on domestic genre-oriented literature and art (illustrations and comics) was positive.

\section{Beginnings of science fiction in Serbia}

For a long time, the development of science fiction (SF) in Serbia was beyond the scope of any systematic research in the history of both literature and popular culture. In the mid-1980s/early 1990s, Aleksandar B. Nedeljković ${ }^{6}$ and Zoran Živković ${ }^{7}$

2 P.J. Marković: Beograd i Evropa: 1918-1941: evropski uticaji na proces modernizacije Beograda [Belgrade and Europe 1918-1941: European Influences on the Modernization of Belgrade], Belgrade 1992; P. Marković, "Društvo međuratnog Beograda — grad prelaznik" [Belgrade Interwar Society - A City in Transition], [in:] Automobil u Beogradu: 1918-1941 [Cars in Belgrade: 1918-1941], Belgrade 2002, p. 15-21.

${ }^{3}$ R. Gašić: Beograd u hodu ka Evropi: Kulturni uticaj Britanije i Nemačke na beogradsku elitu 1918-1941 [Belgrade on the Way to Europe: Cultural Influences of Britan and Germany on Belgrade's Elite], Belgrade 2005.

4 S. Čupić: Građanski modernizam i popularna kultura: epizode modnog, pomodnog i modernog 1918-1941 [Urban Modernism and Popular Culture: Episodes of Vogue, Fad and Modern 1918-1941], Novi Sad 2011.

5 J. Babović, Metropolitan Belgrade: Culture \& Class in Interwar Yugoslavia, Pittsburg 2018.

${ }^{6}$ A.B. Nedeljković, Istorija srpske naučno-fantastične književnosti [The History of Serbian Science Fiction Literature], Belgrade 1985.

7 Z. Živković, Enciklopedija naučne fantastike [Encyclopedia of Science Fiction], Belgrade 1990.

Literatura i Kultura Popularna XXVII, Wrocław 2021

(C) for this edition by CNS 
studied the origins of SF in Serbia. More recently, Bojan Jović ${ }^{8}$ and Miodrag Milovanović ${ }^{9}$ covered the topic in more detail.

The first work published in Serbia which had all the SF traits was a booklet Put na zvezdu Danicu [Travelling to the Morning Star, 1872], an abridged and adapted version of the novel Voyage a Vénus by Achille Eyraud, Serbified by the yet unidentified S.V.S. Many novels by Jules Verne began to be published the very next year, first as serials and later as complete novels. Verne was one of the most popular writers in Serbia before WWI.

Regarding domestic authors of the genre later named "science fiction", by far the most important Serbian work published in the 19th century was the drama "Posle milijon godina" [A Million Years Later], written by Dragutin Ilić and published in 1889 in the magazine Kolo. This work may very well be the first drama in the world with all the elements of the SF genre and its quality matches the best works of the time. The first Serbian novel that incorporates significant SF elements dates back to 1902. It is Jedna ugašena zvezda [An Extinguished Star] by Lazar Komarčić. The novel shows strong influences of theosophy and spiritualism, which might be indicative of a close connection between these two types of prose, also present in the works of other domestic writers, as pointed out by some literary theoreticians. ${ }^{10}$

In general, the novels by Jules Verne and other authors, such as Camille Flammarion, along with domestic works were rather well received by both readers and critics and were a solid foundation for a wider influx of the genre through various forms of popular culture after WWI.

\section{Ilustracija AD publishing company}

The most notable publishers of popular magazines in Serbia, essentially monopolists, were Ivan Zrnić (1888-1942?), his wife Jelena Zrnić, née Jovanović (1890?-1969), and her brother Nikola B. Jovanović (1889-1932). This trio founded the first illustrated magazine in Yugoslavia after WWI - Ilustrovani list [The Illustrated Magazine], which was in print until 1929 and was the most important Yugoslav magazine of its kind. Details of the magazine's origin can be found in the following text:

Exactly five years ago, somehow, in these November days, Jelena and Ivan Zrnić brought the first printed issue of Ilustrovani list from Vienna. [...] Jelena and Ivan Zrnić were the initiators, owners, editors, sole collaborators, haulers and distributors of the first issues of Ilus-

${ }^{8}$ B. Jović, Rađanje žanra: počeci srpske naučno-fantastične književnosti [Birth of a Genre: The Beginnings of Serbian Science Fiction Literature], Belgrade 2006.

9 M. Milovanović, Srpska naučna fantastika [Serbian Science Fiction], Belgrade 2016.

${ }^{10}$ N. Radulović, Podzemni tok: Ezoterično i okultno u srpskoj književnosti [Underground Flow: The Exoteric and Occult in Serbian Literature], Belgrade 2009. 
trovani list. [...] Ilustrovani list appeared in the most appropriate moment, right after the war, when we, tormented, sparse and scattered around the world, had to gather, count and meet anew, to see in an image what our generations have done, and get to know, from and through the image, all the new regions of our extended homeland [Yugoslavia], every corner of it. That is why Ilustrovani list was met with great and equal fondness in Belgrade, Zagreb and Ljubljana, and why it is still present, by strenuously adhering to its program: to get to know and grow close, despite everybody and everything — and that is why it is being read everywhere, from Timok to Soča, on Carev Vrh and on the Adriatic islands. ${ }^{11}$

This was written when the situation in the newly-formed country, the Kingdom of Yugoslavia, had already stabilized after WWI and when the aforementioned trio worked, besides Ilustrovani list, on some other magazines that dealt with separate areas of culture and society: Zabavnik Ilustrovanog lista [The Illustrated Magazine's Entertainer], whose editors-in-chief were Ivan Zrnić and Nikola B. Jovanović; Naša deca [Our children], editor-in-chief Jelena Zrnić; Naš sport [Our Sports], editor-in-chief Vojin M. Đorđević; as well as Comoedia, dedicated to theatrical arts, editors-in-chief Nikola Trajković and Miodrag M. Svetovski, which was an important link to haute culture and featured numerous writers and critics, considered to be the bearers of cultural policy of Serbia and Yugoslavia in the 1920s.

In early 1925, this group formed a publishing association Ilustracija $\mathrm{AD}$, which continued to release these and some new magazines.

Ilustrovani list and Zabavnik Ilustrovanog lista published numerous novels (in installments) and stories that fell into various genres of popular prose, primarily romance, adventure, crime, and the like. Although not as numerous, there were also works belonging to fantastic genres - science fiction, fantasy, supernatural, religious fiction, etc.

Regarding SF novels, what warrants highlighting is the first release of one from among the more important early French science fiction works Dr. Lerne Undergod by Maurice Renard. It is a novel based on The Island of Doctor Moreau by H.G. Wells, to whom it was dedicated. Other works that may be considered science fiction were also published, such as Master of the World by Raoul Bigot and E.M. Laumann and Hearts of Three by Jack London.

\section{Reč $i$ slika magazine}

Besides Ilustrovani list and Comoedia, the most important magazine of the publishing company Ilustracija AD was Reč $i$ slika [Words and Images]. Its first issue was released in January 1926 and the last in April 1927. Ivan Zrnić was the editor-in-chief, Ivan Zrnić and Nikola B. Jovanović were editors. According to introductory comments in the first issue, the intent was to make a Serbian maga-

11 Anonymous, "Pet godina 'Ilustracije"' [Five Years of Ilustracija], Ilustrovani list 1924, no. 48 , pp. $12-14$. 
zine of the mosaic type available, similar to the magazine published by Zaharije Orfelin in the 18th century. Its list of contributors is nothing short of impressive, including masters from all areas of science and art: Milan Grol, Prof. Milan Jovanović-Batut, Svetozar Pribićević, Dr. Siniša Stanković, Petar Konjović, Veljko Petrović, Gustav Krklec, Sibe Miličić, Milan Bogdanović, Bogdan Popović, Isidora Sekulić, Dr. Radovan Kazimirović, Dragutin M. Domjanić, Milan Kašanin, Hamza Humo, Božidar Kovačević, Marko Car, Vladimir Velmar Janković, Branimir Ćosić, Todor Manojlović, and others.

From a historical perspective of fantasy literature reception in Serbia, it is of paramount importance that this magazine was publishing SF stories. In the very first issue, the magazine carried a tale by a domestic author, Bran. Dinitrijević, "Posle sto godina" [A Hundred Years After], sub-headed "verovatna priča" [a possible story]. It is a classic SF story criticizing current social developments by projecting them to the extreme into a semi-ironic, extrapolated vision of the future.

Several other SF stories appeared in this magazine: "Neobičan svet - Život i doživljaji Ivana Petrovića" [An Extraordinary World — Life and Adventures of Ivan Petrović] by Siniša Kordić, published in the July 1926 issue. This story was later incorporated into the novel Neobičan svet [An Extraordinary World]. The December 1926 issue carried Branimir Ćosić's tale "Egipćanka" [Egyptian Woman], later published in a collection of the same title. Critics classified both of these works under the opus of Serbian avant-garde literature.

However, although the appearance of these stories in the Reč $i$ slika magazine is significant for investigating the links between domestic fantastic and avant-garde literature, if the importation of some events from the world's popular literature is considered, it is much more significant that some stories, together with original or slightly modified illustrations, appeared in the magazine soon after they were released on a global scale. These are the stories published in the world's first specialized SF magazine, Amazing Stories, founded by Hugo Gernsback in April 1926 in the USA.

In the introductory comments on the first issue, Hugo Gernsback states that the magazine will not be just another fiction magazine, "but a magazine of 'Scientifiction', a pioneer in its field in America". In the very next sentence he clarifies: "By 'scientifiction' I mean the Jules Verne, H.G. Wells and Edgar Allan Poe type of story - a charming romance intermingled with scientific fact and prophetic vision". 12

Although Reč i slika was a mosaic magazine, according to its editors, in its first issues it included stories that doubtless belonged to the type defined by Hugo Gernsback. Besides the domestic tale "Posle sto godina" [A Hundred Years After] in the April issue, it carried a story by H.G. Wells — "The Diamond Maker".

12 H. Gernsback, “A New Sort of Magazine”, Amazing Stories 1, 1926, no. 1, p. 3. 
However, most interestingly, as early as the August issue, the magazine carried the story "Jaja sa jezera Tanjganjike" [The Eggs from Lake Tanganyika] by the German author Curt Siodmak published in the USA only one month earlier, in the July edition of Amazing Stories. Given the year of these events, knowing that it was necessary for a copy to be literally shipped across the Atlantic and then translated, and that it had to be illustrated according to the original — it all seems almost incredible.

Although Hugo Gernsback claimed in the introduction that the story was original, it was actually a translation of "Die Eier vom Tanganjikasee", published in February of the same year in the German Scherl's Magazine. It is reminiscent of some early H.G. Wells' stories, but with elements of mild irony.
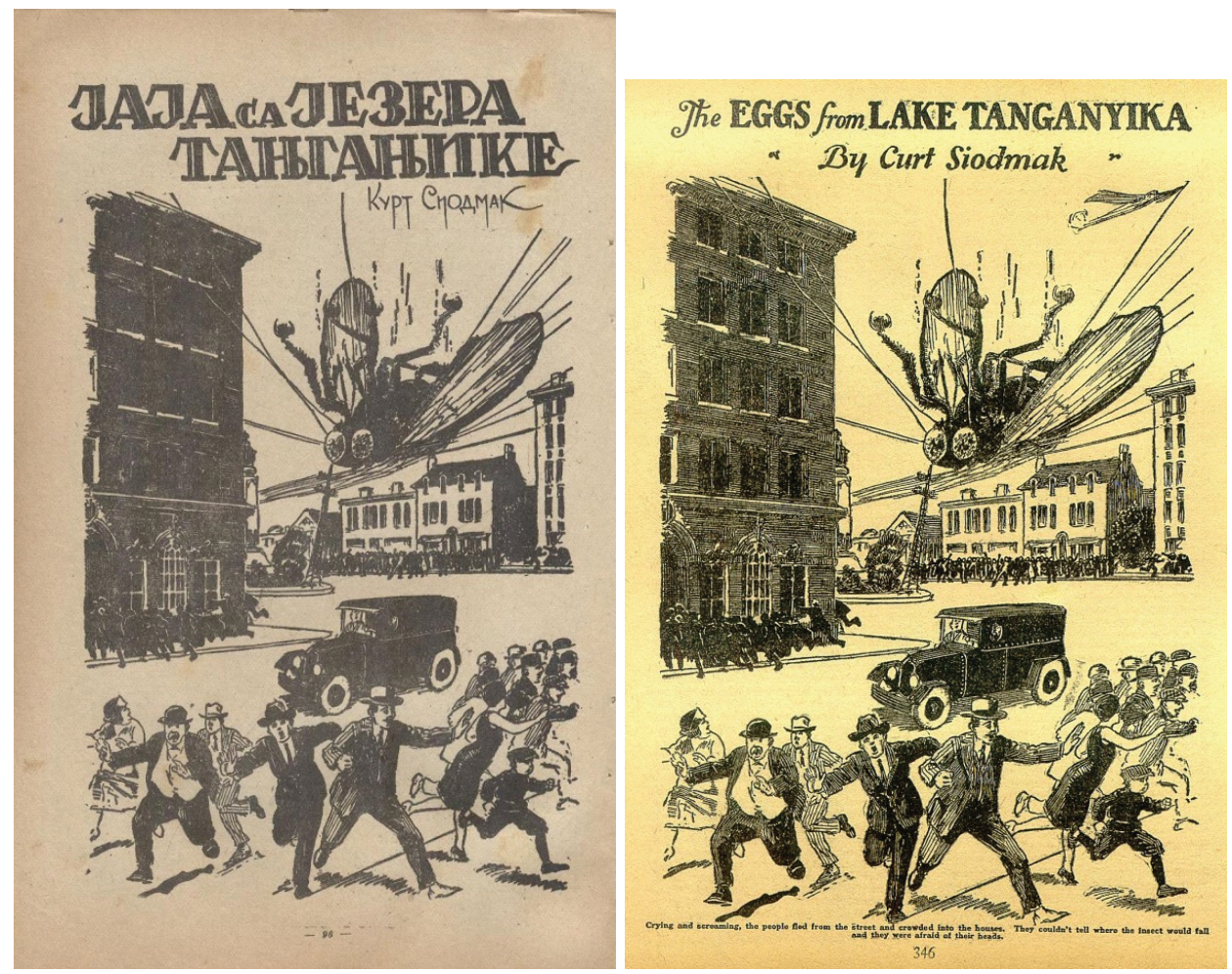

Figure 1. Illustration for "The Eggs from Lake Tanganyika" in Reč i slika vs. Amazing Stories

It is obvious that Amazing Stories was regular reading material in the editorial office of Reč $i$ slika, as the following issues also contained stories taken from this world-pioneering SF magazine.

The December 1926 issue carried the story "Na dnu Okeana" [In the Abyss], sub-headed "A tale of fantasy by H.G. Wells (Illustrated by L. Beljski. Translated by J.)". The initial of the translator and the translation quality suggest that the 

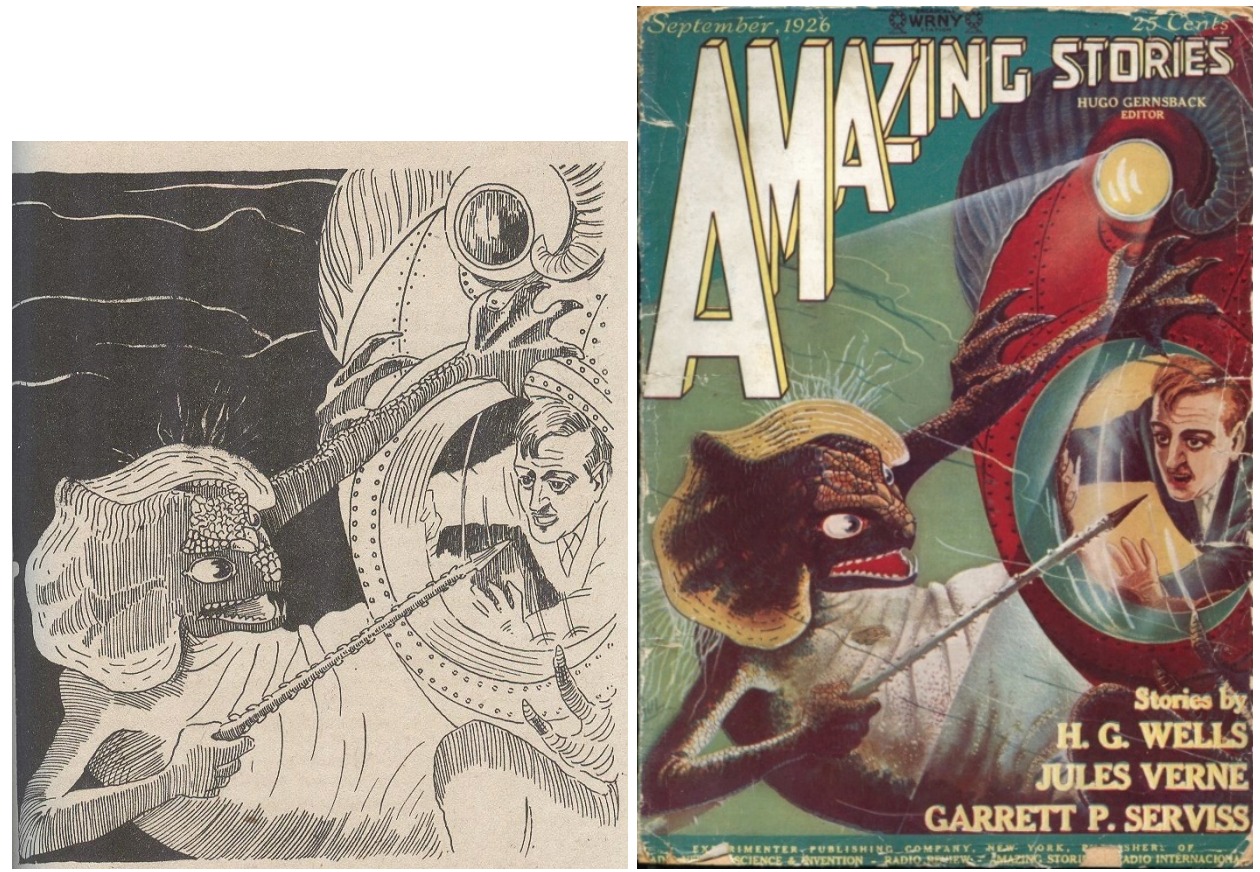

Figure 2. Illustration for the story "In the Abyss" in Reč $i$ slika vs. Amazing Stories

translator might have been the magazine editor himself, Nikola B. Jovanović, who rarely signed his translations in the magazines he edited.

The February 1927 issue contained the story "Prekidač vremena", a translation of "The Time Eliminator", originally published in the December 1926 issue of Amazing Stories. The author of that story is anonymous, signed under the pseudonym KAW.

Apart from the importance of introducing to the domestic readership tales from around the world, which at that time served as the foundation of a specific literary genre, publishing these stories certainly influenced a number of domestic illustrators and comics creators who familiarized themselves with the works of the best contemporary genre artists from the United States, primarily Frank R. Paul, and thereby improved their own skills.

The Reč $i$ slika magazine paid special attention to graphic design. Cover illustrations were occasionally commissioned from leading Serbian artists, such as Dragoslav Stojanović, who illustrated the cover and several pages of the first issue, which also contained a long article about him. Several issues, including one cover page, were illustrated by Bogoslav Konjevod, an artist close to avant-garde circles and one of the actors in the first domestic avant-garde movie Kačaci u Holivudu [Kachaks in Hollywood], which was never finished. Quality was also prominent 

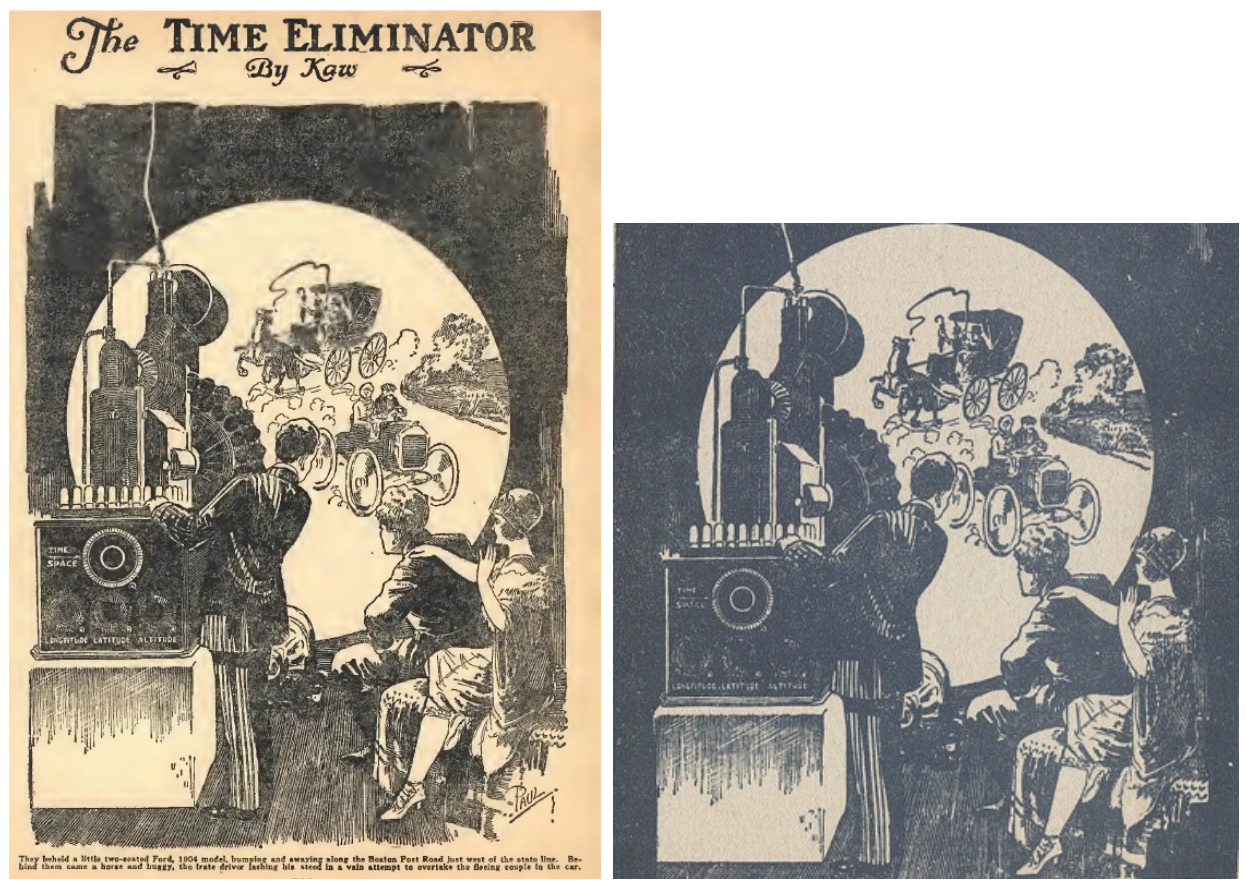

Figure 3. Illustration for the story "The Time Eliminator" in Amazing Stories vs. Reč i slika

in the works of the already mentioned Leon Beljski, as well as Boško Zrakić "Ruffo" and Miloš R. Vušković. ${ }^{13}$

Regarding domestic writers, it is evident that in the 1930s there was an increasing number of works that could be classified as SF or a sort of fantasy prose with elements of SF. Establishing their direct link to the stories from Rec $i$ slika is difficult, but it is interesting to note that two authors who published in this magazine, Vladimir Velmar Janković ${ }^{14}$ and Mladen St. Đuričić, ${ }^{15}$ later released some interesting genre works well received by the domestic readership.

Unfortunately, it is still unknown how a magazine that was only beginning to gain a foothold in the US got an express lane to Serbia. The fact that texts from Amazing Stories were published in a domestic magazine is a curiosity by itself. It should be kept in mind that research of popular culture in Serbia is greatly hindered by the fact that nearly the entire prewar National Library repository was lost during the German bombing of Belgrade in April 1941, and that, when it was renewed after the war, popular magazines received only limited attention.

13 B. Popović: Primenjena umetnost i Beograd: 1918-1941 [Contemporary Art and Belgrade: 1918-1941], Belgrade 2011, p. 166.

${ }^{14}$ Unknown [V. Velmar Janković], Sreća A.D. = Interkontinentalni spektakl u četiri čina s prologom [Sreća AD = Intercontinental Spectacle in Four Acts with a Prologue], Belgrade 1933.

15 M. St. Đuričić, Mrtva straža [The Dead Sentry], Belgrade 1939. 


\section{Conclusion}

Beginning with the claim of historian Jovana Babovic that in the 1920s Belgrade was inundated with foreign cultural influences: jazz, cabaret, radio, film, etc., which its residents embraced with open arms as symbols of inclusion in modern world trends, an attempt was made to corroborate this assertion by analyzing the influences in a specific area of popular culture, which at that time was still in its infancy - science fiction. Various examples were found which supported her claim, expanding it with interesting findings about the surprisingly fast transfer of that genre to the Balkans.

It is almost certain that the mainstays of popular culture in Belgrade of the 1920s, gathered around the publishing house Ilustracija, tried to introduce their readership to contemporary trends as far as possible, increasingly drawing from US popular culture - science fiction and later comics. Thus, it comes as no surprise that, unlike the "official" culture, influenced mostly by French, German, and Russian ideals, including representatives of the avant-garde, the ingress of US influence occurred mostly through popular culture.

On the other hand, in the field of entertainment, there appears to have been no negative influence on domestic authors of science fiction prose and comics. Quite the contrary: exposing Serbian and Yugoslav visual artists and scriptwriters to these works improved the quality of their own work and later led to the creation of comics and graphic novels relevant both in Europe and on a global scale. ${ }^{16}$ The same could be said of Serbian science fiction writers between the two World Wars, but they unfortunately reached contemporary readers with a long delay due to the discontinuity caused by WWII and the situation in the recreated post-war state.

What was it that made the US popular culture readily acceptable to the Belgrade/Serbian audience in the 1920s? This is a highly complex question which would require elaboration and extensive multidisciplinary research. It is difficult to ascertain whether it was the absence of a dominant European cultural influence that made it easy for the rather aggressive US propaganda machine after World War I to reach consumers. In any case, the room for further research of this phenomenon remains wide open.

16 Z. Stefanović, "U potrazi za papirnim Holivudom” [In Search of Paper Hollywood], [in:] I. Anastasijević et al., Ruski strip Kraljevine Jugoslavije [Russian Comic Strip in the Kingdom of Yugoslavia], Russian Emigrant Heritage Conservation Society, "Altera" Archives, Moscow-Belgrade 2018 . 


\title{
Bibliography
}

Babović J., Metropolitan Belgrade: Culture \& Class in Interwar Yugoslavia, University of Pittsburgh Press, Pittsburg 2018.

Čupić S., Građanski modernizam i popularna kultura: epizode modnog, pomodnog i modernog 1918-1941, Galerija Matice srpske, Novi Sad 2011.

Dimitrijević B., "Posle sto godina", Reč i slika 1926, no. 1.

Gašić R., Beograd u hodu ka Evropi: Kulturni uticaj Britanije i Nemačke na beogradsku elitu 19181941, Institut za savremenu istoriju, Beograd 2005.

Jović B., Rađanje žanra: počeci srpske naučno-fantastične književnosti, Institut za književnost i umetnost, Beograd 2006.

Marković P.J., Beograd i Evropa: 1918-1941: evropski uticaji na proces modernizacije Beograda, Savremena administracija, Beograd 1992.

Marković P., "Društvo međuratnog Beograda - grad prelaznik", [in:] Automobil u Beogradu: 1918-1941, Muzej automobila, Beograd 2002.

Milovanović M., Srpska naučna fantastika, Everest Media, Beograd 2016.

Nedeljković A.B., Istorija srpske naučno-fantastične književnosti, own publication, Beograd 1985.

Popović B., Primenjena umetnost i Beograd: 1918-1941, Muzej primenjenih umetnosti, Beograd 2011.

Radulović N., Podzemni tok: Ezoterično i okultno u srpskoj književnosti, Službeni glasnik, Beo$\operatorname{grad} 2009$.

Stefanović Z., "U potrazi za papirnim Holivudom”, [in:] I. Anastasijević et al. Ruski strip Kraljevine Jugoslavije, catalogue of the exhibition, Russian Emigrant Heritage Conservation Society, "Altera” Archives, Moskva-Beograd 2018.

Zupan Z., Vek stripa u Srbiji, Kulturni centar — Galerija savremene umetnosti, Pančevo 2007.

Živković Z., Enciklopedija naučne fantastike, "Prosveta”, Beograd 1990.

\section{Science Fiction in Belgrade in the 1920s: A Possible Contribution to the Development of Metropolitan Belgrade}

\author{
Summary
}

Historian Jovana Babović claims that post-World War I Belgrade residents embraced different foreign cultural influences in an attempt to become citizens of western type metropolis. Various examples that support her claim were discovered through analysing a specific area of popular culture - science fiction - and enriched with interesting findings about surprisingly fast translations of certain stories, at the very beginning of the establishment of science fiction as an independent genre by Hugo Gernsback, publisher of the world's first SF magazine Amazing Stories (1926). Several stories from its first issues appeared after only a few months in the Belgrade magazine Reč $i$ slika [Words and Images], with faithful copies by domestic illustrators of original drawings by the leading US genre illustrator of that time, Frank R. Paul.

Despite the relatively small number of translated stories, influence on domestic writers and illustrators of popular fiction was significant. The importance of these stories is reflected in the growing penetration of Serbian popular culture by US influences, which began to gain significance in relation to the hitherto dominant French, German and Russian influences.

Unfortunately, considering that most of the people involved in these activities died during World War II, and that there is no archived documentation, the pathways by which these stories reached readers in Serbia have yet to be uncovered.

Literatura i Kultura Popularna XXVII, Wrocław 2021

(C) for this edition by CNS 